\title{
Geodynamics of the SW Pacific: a brief review and relations with New Caledonian geology
}

\author{
Collot Julien ${ }^{1,{ }^{*}}$, Patriat Martin ${ }^{2}$, Sutherland R. ${ }^{3}$, Williams S. ${ }^{4,5}$, Cluzel D. ${ }^{6}$, Seton M. ${ }^{4,5}$, Pelletier B. ${ }^{7}$, \\ Roest Walter ${ }^{2,8}$, Etienne S. ${ }^{1}$, Bordenave A. ${ }^{1,8}$, Maurizot P. ${ }^{1}$
}

1 Service Géologique de Nouvelle-Calédonie (New Caledonia Geological Survey), BP M2, 98849

Nouméa, New Caledonia

2 Ifremer, UR Géosciences Marines, 29280 Plouzané, France

3 Victoria University of Wellington, PO Box 600, Wellington 6140, New Zealand

${ }^{4}$ EarthByte Group, School of Geosciences, The University of Sydney, NSW 2006, Australia

${ }^{5}$ State Key Laboratory of Continental Dynamics, Department of Geology, Northwest University, Xían,

China

${ }^{6}$ University of New Caledonia, ISEA-EA 7484, BP R4, 98851 Nouméa, New Caledonia

${ }^{7}$ Geosciences Azur (UMR 6526), IRD, 101 Promenade R. Laroque, BP A5, 98800 Nouméa, New

Caledonia

${ }^{8}$ ENSEGID, Bordeaux INP, 1 allée F. Daguin, 33607 Pessac Cedex, France

* Corresponding author : Julien Collot, email address : Julien.collot@gouv.nc

\begin{abstract}
:
The SW Pacific region consists of a succession of ridges and basins that were created by the fragmentation of Gondwana and the evolution of subduction zones since Mesozoic times. This complex geodynamic evolution shaped the geology of New Caledonia, which lies in the northern part of the Zealandia continent. Alternative tectonic models have been postulated. Most models agree that New Caledonia was situated on an active plate margin of eastern Gondwana during the Mesozoic. Extension affected the region from the Late Cretaceous to the Paleocene and models for this period vary in the location and nature of the plate boundary between the Pacific and Australian plates. Eocene regional tectonic contraction included the obduction of a mantle-derived Peridotite Nappe in New Caledonia. In one class of model, this contractional phase was controlled by an east-dipping subduction zone into which the Norfolk Ridge jammed, whereas and in a second class of model this phase corresponds to the initiation of the west-dipping Tonga-Kermadec subduction zone. Neogene tectonics of the region near New Caledonia was dominated by the eastwards retreat of Tonga-Kermadec subduction, leading to the opening of a back-arc basin east of New Caledonia, and the initiation and southwestwards advance of the New Hebrides-Vanuatu subduction zone towards New Caledonia.
\end{abstract}




\section{Geological structures of the southwest Pacific}

New Caledonia sits at the northeastern extremity of the Australian Plate, close to the PacificAustralia plate boundary. Its onland and offshore geology provides important information on the geodynamic evolution of the southwest Pacific (Fig. 1 and fold out geological map, this memoir). Present day physiography and geology of the region has resulted from fragmentation of eastern Gondwana since the Mesozoic by successive basin openings and closures associated with the evolution of subduction zones. Basin closures led in some places to folding, faulting and obduction of nappes during the Cenozoic, including nappes containing ophiolitic material in Papua New Guinea, New Caledonia, and New Zealand.

Central to describing and understanding the bathymetry and geology of the southwest Pacific is the 94\% submerged continent of Zealandia [Mortimer et al., 2017]. Zealandia is composed of a succession of continental ridges (from west to east): the Dampier Ridge, Lord Howe Rise, Fairway Ridge and Norfolk Ridge. Each ridge and intervening trough has a clear expression on the free air gravity anomaly map (Fig. 1). New Caledonia is located at the northern end of Norfolk Ridge. The continental ridges are separated from each other by basins (of probable continental type). From west to east these are the Middleton Basin, Fairway-Aotea Basin, and New Caledonia Trough. Crustal thicknesses vary from ca. $25 \mathrm{~km}$ beneath ridges to $10-15 \mathrm{~km}$ in the basins [Klingelhoefer et al., 2007]. Water-depths of Zealandia are typically 1000-1500 m for the ridges, down to $2000 \mathrm{~m}$ in the Fairway Basin, and ca. $3500 \mathrm{~m}$ in the New Caledonia Trough near New Caledonia.

Zealandia is surrounded by oceanic basins, back-arc basins and subduction-related volcanic ridges of various ages. Between Zealandia and Australia are the Tasman and Coral seas, two $2000 \mathrm{~km}$ wide Late Cretaceous to early Eocene ocean basins containing central spreading centres and sets of continuous distinct oceanic fracture zones (Fig. 2). The area to the east of Zealandia is predominantly composed of Cenozoic volcanic ridges that, with exception to the New Hebrides-Vanuatu arc, are generally younger to the east: Loyalty Ridge, Three Kings Ridge, Lau-Colville Ridge, Tonga-Kermadec Ridge and the New Hebrides-Vanuatu arc. The latter two, although resulting from oppositely-dipping subduction zones, are active with subduction-related volcanic arcs. Between the ridges are back-arc basins: Norfolk, South Fiji, Lau-Havre, and North Fiji basins. In contrast to the Tasman and Coral Sea basins, these back-arc basins contain short-segment, poorly-organised spreading centres and have few prominent fracture zones (Figs. 2 and 3).

Other prominent features of the southwest Pacific are three age-progressive volcanic 'hotspot' tracks that may approximate motion of the Pacific and Australian plates relative to the mantle during the Cenozoic [Knesel et al., 2008; McDougall and Duncan, 1988; McDougall et al., 1981; Missègue and Collot, 1987; Mortimer et al., 2018]. The Louisville chain is on the Pacific Plate and the Tasmantid and Lord Howe chains are on the Australian plate (Fig. 1).

\section{$\underline{\text { Geodynamics }}$}

\section{Present day geodynamics}

The southwest Pacific is tectonically active with very rapid motion between two opposite subduction zones, and active back-arc extension. The Mesozoic Pacific plate is subducted at the Tonga-Kermadec trench at rates that increase northward. At $16^{\circ} \mathrm{S}$ the convergence rate reaches $24 \mathrm{~cm} /$ year, which is 
the fastest convergence rate on Earth [Bevis et al., 1995; Pelletier and Louat, 1989; Pelletier et al., 1998]. The convergence rate corresponds to the sum of the Australia-Pacific relative plate motion rate and the Lau basin spreading rate, which is a measure of the rate of trench retreat (see Heuret and Lallemand [2005] for more details). The Australian plate moves NNE at a rate of $7 \mathrm{~cm} /$ year relative to Antarctica [Petterson et al., 1999] and is subducted along the New Hebrides-Vanuatu trench beneath the Pacific Plate at a rate of up to $17 \mathrm{~cm} /$ year [Bergeot et al., 2009; Calmant et al., 2003; Dubois et al., 1977; Pelletier et al., 1998]. The Fiji Fracture Zone (see location on Fig. 2 and 3), combined with a complex system of spreading ridges and transform faults in the North-Fiji Basin, accommodates motion between the Australian and Pacific plates [Pelletier et al., 1998; Pelletier et al., 2001] (Fig. 2 and 3). The northeastern part of the Australian plate is being subducted along the New Hebrides-Vanuatu trench. South of New Zealand, the Pacific-Australian plate boundary has a dextral strike-slip rate of c. $3 \mathrm{~cm} / \mathrm{yr}$, and has evolved from extension to compression since the Eocene, with oblique subduction of the Australian plate initiating at the Puysegur Trench during the Miocene [Collot et al., 1995; Lamarche and Lebrun, 2000; Sutherland et al., 2000; Sutherland et al., 2009].

\section{$\underline{\text { Mesozoic and Cenozoic geodynamics }}$}

Various conceptual geodynamic and tectonic models have attempted to explain the formation and development of the southwest Pacific in time and space, e.g. [Ballance et al., 1982; Cluzel et al., 2001; Crawford et al., 2003a; Hall, 2002; Karig, 1971; Kroenke, 1984; Müller et al., 2000; Schellart et al., 2006; Sdrolias et al., 2003; Veevers, 2000; Yan and Kroenke, 1993]. Most geodynamic models of the southwest Pacific follow the model of Karig [1971], which, based on examples from the western Pacific region, introduced the concept that roll-back of a subducted slab may induce oceanward retreat of the subduction trench, extension behind the arc, and associated formation of a series of remnant arcs and back-arc basins.

Magnetic anomalies of the Tasman and Coral seas show that oceanic crust formed from the Late Cretaceous to Early Eocene (Figs. 2 \& 3) [Gaina et al., 1998; Hayes and Ringis, 1973]. The New Caledonia Trough, Fairway and Norfolk basins have a more contentious origin and may be underlain by oceanic crust, continental crust, thinned continental crust, or exposed/denuded mantle. Their ages are more difficult to constrain. Moreover, the long history of subduction in the region has led to the recycling of large swaths of lithosphere into the mantle, thus obliterating much of the geological record (e.g. magnetic anomalies, age and nature of crust and extent of the basin) in some areas. As a result, elements of the geodynamic evolution of the southwest Pacific remain poorly controlled and several alternative conceptual models exist. We review below some of the alternate models.

\section{Mesozoic Gondwana subduction}

The belt-like distribution of deformed Permian to Early Cretaceous trench-slope and fore-arc basin sedimentary rocks, arc volcanic and intrusive rocks in New Caledonia and New Zealand (eastern Zealandia) shows that a Pacific basin subducting slab dipped southwest beneath the eastern margin of Gondwana throughout much of the 260-110 Ma interval ([Bradshaw, 1981; Cluzel et al., 2010b; Mortimer et al., 2008; Mortimer et al., 2009; Sdrolias et al., 2003]. Some geodynamic models propose that this was complicated by opening and closing of marginal basins and involved local changes in trench location and/or periods with opposite subduction vergence [Adams et al., 2009; Li et al., 2012] and chapter 3 this memoir. Evidence for existence of a Mesozoic volcanic arc along the paleo- 
margin of Gondwana comes from the accumulation of Mesozoic volcaniclastic sediments of considerable thickness in the Otway and Gippsland basins (located between Australia and Tasmania), the Great Artesian Basin (located in the middle of the Australian continent), in New Zealand, and in New Caledonia (cf. Chapter 3, this memoir). More directly, Mortimer et al. [2008; 2002; 1999] show that roots of the Mesozoic continental arc are exposed as the Median Batholith in New Zealand, as well as equivalents in Marie Byrd Land, Antarctica, Queensland, and dredged rocks from offshore Zealandia (e.g. West Norfolk Ridge). Late Mesozoic subduction at the Gondwana margin correspond to the long-lived subduction that runs from northeast of Australia to South America, and that subsequently died adjacent to Zealandia and Antarctica, but remains active today beneath South America (Fig. 4).

\section{Late Cretaceous - Palaeocene extension}

At c. $110-100 \mathrm{Ma}$ (end Early Cretaceous), the regional tectonic regime along the Pacific margin of Gondwana changed from convergent to extensional. An episode of intracontinental rifting lasted until at least c. $85 \mathrm{Ma}$ along much of the Gondwana margin, at which time Zealandia began to separate from Gondwana. As well as the termination of deformation and metamorphism in accretionary subduction complexes, there was a switch from subduction-type to rift-type magmatism in New Zealand and New Caledonia in the Early to early Late Cretaceous [Cluzel et al., 2010b; Mortimer, 2004; Muir et al., 1995; Tulloch et al., 2009]. Widespread sedimentary basins associated with normal faulting during the interval c. 105-80 Ma are found throughout Zealandia (in New Caledonia (cf. Chapter 4, this memoir), Lord Howe Rise, New Zealand, Campbell Plateau) and in West Antarctica [Bache et al., 2013; Carter et al., 1992; Herzer et al., 1997; Laird, 1992; Luyendyk et al., 2003; Luyendyk et al., 2001; Rouillard et al., 2017; Van der Lingen et al., 1973]. It has been suggested that a fundamental cause of this tectonic change from subduction to rifting was due to jamming of subduction by the Hikurangi Plateau at c. 105 Ma [Collot et al., 2009; Davy et al., 2008]. An alternative is waning subduction associated with the interaction of the trench with adjacent spreading ridges [Matthews et al., 2012]. Initial breakup of Zealandia from Gondwana is dated at 83$79 \mathrm{Ma}$ (chron 33r), based on marine magnetic anomalies adjacent to much of Zealandia in the Tasman Sea, and propagated towards the North until $57 \mathrm{Ma}$ (chron 26) [Gaina et al., 1998]. Initial break-up may have occurred slightly earlier at the southern extremity of the Tasman Sea (chron 34) [Gaina et al., 1998; Sutherland, 1999]. The Tasman Sea spreading centre was active until $52 \mathrm{Ma}$ (chron 24), and the resulting oceanic seafloor provides a record of relative plate motions between Gondwana and Zealandia [Gaina et al., 1998].

Tectonic models of Late Cretaceous to Early Eocene plate kinematics in the southwest Pacific vary in the nature of plate boundary east of Zealandia. Options include an east-dipping subduction zone, a west-dipping subduction zone, a strike-slip boundary, or no boundary at all.

In one class of geodynamic model (model A, Fig. 5 and 6), the Tasman Sea, New Caledonia Trough and South Loyalty Basin are inferred to be back-arc basins, with extension driven by a west-dipping subduction zone retreating towards the Pacific via a rollback process [Cluzel et al., 2012a; Crawford et al., 2003a; Gaina et al., 1998; Hall and Spakman, 2002; Schellart et al., 2006; Sdrolias et al., 2001; 2003]. The South Loyalty Basin would once have been much wider with its back-arc basin oceanic crust now telescoped and obducted in allochthons of the Poya Terrane (cf. chapter 5, this memoir) in New Caledonia [Aitchison et al., 1995; Cluzel et al., 2001; Cluzel et al., 2018; Eissen et al., 1998] and 
of the Tangihua and Makatoa Volcanics in New Zealand [Cluzel et al., 2010a; Nicholson et al., 2000a; Nicholson et al., 2000b]. It is notable that arc volcanic rocks for this period have not been conclusively discovered [Mortimer et al., 2018; Pelletier, 2007].

An alternative class of model has eastern Gondwana subduction cessation followed by divergent plate motions (initially intracontinental, then at spreading ridges) that led to rifting of Gondwana, breakup, and then opening of the Southern Ocean and Tasman Sea [Gaina et al., 1998; Norvick et al., 2008; Sdrolias et al., 2001; 2003; van der Meer et al., 2016; Williams et al., 2011]. In this class of model (model B, Fig. 5 and 6), the Late Cretaceous plate boundary between Zealandia and the Pacific Plate is either thought to be inactive [Pirard and Spandler, 2017; Steinberger et al., 2004], or to be a transform boundary [Müller et al., 2000; Richards and Lithgow-Bertelloni, 1996]. In this class of model, the South Loyalty Basin could be a relic of the Pacific Plate, or could be connected with Coral Sea spreading.

\section{Eocene contraction}

Most authors agree that a phase of regional tectonic contraction started during the latest Palaeocene or Eocene (cf. Chapter 4 and 5, this memoir), though the precise magnitude, extent, timing and duration of this phase remains debated [Ballance, 1999; Ballance et al., 1982; Cluzel et al., 2001; Crawford et al., 2003a; Dallanave et al., 2018; Kroenke, 1984; Maurizot, 2012; Schellart et al., 2006; Sdrolias et al., 2003; Sutherland et al., 2010; Sutherland et al., 2017; Whattam et al., 2008]. In New Caledonia, this phase culminates with obduction of the Peridotite Nappe during the latest Eocene. Lower strain regional Eocene contraction is observed on seismic-reflection data across Zealandia and in eastern Australia [Bache et al., 2012; Etienne et al., 2017; Lafoy et al., 1994; Rouillard et al., 2017; Sutherland et al., 2010; Sutherland et al., 2017].

The first class of model (Model A, Fig. 5 and 6) proposes that a new east-dipping subduction zone initiated in the South Loyalty Basin, possibly near a spreading ridge at c. $56 \mathrm{Ma}$ [Cluzel et al., 2006; Cluzel et al., 2012b; Cluzel et al., 2016; Ulrich et al., 2010]; and then retreated towards the west until c. $34 \mathrm{Ma}$, when the Norfolk Ridge arrived at the trench and blocked it [Aitchison et al., 1995]. In this class of model, the South Loyalty Basin is almost entirely consumed by the second east-dipping subduction zone. The change in subduction polarity at c. $56 \mathrm{Ma}$ (subduction flip from westward to eastward slab dip) is invoked to explain southward propagation of Eocene foreland basins and emplacement of nappes (cf. Chapter 4, this memoir), supra-subduction features within the allochthons, and eclogite-blueschist (high-pressure low-temperature) metamorphism in northern New Caledonia (cf. Chapter 5, this memoir).

In a second class of model (Model B, Fig. 5 and 6), the west-dipping Gondwana subduction zone that died at the start of the Late Cretaceous re-initiated at c. 50 Ma [Gurnis et al., 2004; Steinberger et al., 2004]. In this class of model, new subduction zones initiated throughout the western Pacific during the Eocene (see Miles et al. [2016]) and are associated with changes in Pacific Plate motion manifest as the Emperor-Hawaii seamount bend [O'Connor et al., 2013; Steinberger et al., 2004].

Although the first class of model can explain the Cenozoic geology of New Caledonia, latest Cretaceous, Palaeocene, or Eocene volcanic arc material related to the proposed subduction zone have yet to be found in the southwest Pacific [Matthews et al., 2015; Mortimer et al., 2018]. The exception is arc material recovered from Bougainville Seamount near the New Hebrides-Vanuatu 
trench (see Fig. 1 for location), which was dated as Late Eocene [Collot et al., 1992; Greene et al., 1994] and along the D'Entrecasteaux Ridge [Maillet et al., 1983; Mortimer et al., 2014]. However, the relationship between the Bougainville Seamount, D'Entrecasteaux Ridge, Loyalty Ridge and an eastward-dipping subduction system is not clear (cf. Chapter 6 , this memoir). The second model does not provide a simple explanation for the mechanisms of emplacement of ophiolites in New Caledonia (in the context of southwest-dipping subduction). However, Spörli et al. [1992] and Mortimer et al. [2003] have suggested 'flake tectonic' emplacement of the Northland Allochthon in this configuration. For more details on the geodynamic evolution of this time period, Matthews et al. [2015] give a comprehensive analysis and discussion of the available geological and kinematic data.

\section{Oligocene to present-day Tonga-Kermadec subduction}

There are an increasing number of dredged rock samples from marginal basins and ridges between the Norfolk Ridge and the Tonga-Kermadec trench. They reveal an overall history of west-to-east Tonga-Kermadec subduction roll-back to its present-day position, although locally uncertainties of subduction polarity exist during the Oligocene.

In one class of model (Model A, Fig. 5 and 6), the jamming of east-dipping South Loyalty subduction occurs during the latest Eocene in New Caledonia, and propagates to New Zealand throughout the Oligocene [Whattam et al., 2008]. This propagation explains diachronous ophiolite emplacement: Eocene in New Caledonia (cf. Chapter 5, this memoir), to Oligocene in Northland, New Zealand [Ballance and Sporli, 1979; Malpas et al., 1992; Ruohong et al., 2014]. In this model, west-dipping Tonga Kermadec subduction initiates during or just following this jamming, as a subduction flip.

In the second class of model (Model B, Fig. 5 and 6), west-dipping Tonga Kermadec subduction initiates along Zealandia's eastern margin during the Eocene, and then retreats towards the east from Eocene to present-day. The pole of rotation describing motion across the retreating trench is inferred to have been close to New Zealand. Deformation continued from the Eocene to present-day in the south (New Zealand), but was restricted to a pulse of Eocene deformation in the north, as trench retreat towards the east isolated New Caledonia.

For the Neogene, all models are similar. As Tonga Kermadec subduction retreated towards the east, it preserved a series of remnant volcanic arcs and back arc basins on the overriding plate.

Models predict that the North Loyalty Basin formed during the Eocene and Oligocene [Mortimer et al., 2014; Sdrolias et al., 2003], and the South Fiji Basin formed during the Oligocene to early Miocene [Davey, 1982; Herzer et al., 2011; Malahoff et al., 1982; Mortimer et al., 2007; Watts et al., 1977]. The Loyalty-Three Kings volcanic arc and Norfolk basin formed in the Oligocene and Miocene. [Mortimer et al., 1998; Nicholson et al., 2008].

Arc volcanism in Fiji started in the latest Eocene or Oligocene [Gill, 1987]. Subduction-related lavas of Oligocene age have been found on the Three Kings Ridge [Mortimer et al., 2007]. Medium-K and high-K lavas of late Oligocene age on the northern Norfolk Ridge and early Miocene age near Three Kings Ridge are interpreted as an additional magmatic response to rapid Tonga-Kermadec subduction retreat [Mauffret et al., 2002; Mortimer et al., 2014]. The Lau-Colville volcanic arc is presumed to have been active during the Miocene [Ballance et al., 1982; Hawkins, 1995] but is sparsely sampled 
compared with other ridges in the region. Its activity appears to be coeval with formation of the South Fiji Basin, and cessation of Colville arc activity is interpreted to have resulted from intra-arc tearing associated with slab roll-back and creation of the Lau Basin in the north and the Havre Trough in the south. This isolated the active Tonga Kermadec arc [Hawkins, 1995]. The oldest rocks dated in ODP 841 drill hole in the Tonga fore-arc cluster around $45 \mathrm{Ma}$, with the oldest being $46 \mathrm{Ma}$ [McDougall et al., 1994]. A similar age range has been found from 'Eua, an island on the Tonga platform [Duncan et al., 1985]. Studies of the Tonga fore-arc have dredged ultramafic and subduction-related volcanic rocks as old as 52-48 Ma [Bloomer et al., 1995; Meffre et al., 2012]. The Lau Basin and Havre Trough formed since the late Miocene or Pliocene [Malahoff et al., 1982; Parson and Wright, 1996; Sdrolias et al., 2003; Taylor et al., 1996]. These active basins have been extensively studied, with particular emphasis on their petrological and geochemical signatures. Oceanic accretion occurs along two major spreading ridges that are propagating south: the Valu Fa Ridge and the Lau Ridge [Hawkins, 1995]. Ocean floor consists of MORB-type basalts, except in the west of the basin, where a mixture of MORB is found along with transitional rocks and volcanic arc basalts (arc tholeiites). Seismic-refraction data shows that the western basin consists of $\sim 100 \mathrm{~km}$ width of thinned crust, probably stretched arc, and the eastern basin contains a $\sim 200 \mathrm{~km}$ width of $8-9 \mathrm{~km}$ thick oceanic crust [Crawford et al., 2003b]. Spreading rates of 4-9.5 cm/year are comparable with those at the East Pacific Rise [Bevis et al., 1995].

The area north of New Caledonia remains poorly studied. Geophysical and dredge sample data have identified the South Rennell Trough and Santa Cruz Basin as an early Oligocene fossil spreading ridge [Mortimer et al., 2014; Seton et al., 2016], with the age of the flanking D'Entrecasteaux Basin largely unconstrained.

\section{Miocene to present-day New Hebrides-Vanuatu subduction initiation and retreat}

At the end of the Middle Miocene, the northeast-dipping New Hebrides-Vanuatu subduction zone initiated along the Vitiaz lineament, possibly in relation to a subduction flip induced by collision of the Ontong Java and Melanesian Border plateaus with the Vitiaz subduction zone [Auzende et al., 1988b; Brocher, 1985; Chase, 1971; Falvey, 1975; Pelletier and Auzende, 1996]. The reconfigured subduction zone then formed the Solomon-Vanuatu arc and rolled back towards the south and southwest, leading to opening of the North Fiji Basin [Auzende et al., 1995a; Auzende et al., 1988a; Auzende et al., 1995b]. Zircons found within the arc suggest that part of the Vanuatu basement comprises old continental material that was rifted and transported thousands of kilometres from northeastern Australia prior to the Cenozoic [Buys et al., 2014]. The d'Entrecasteaux and Loyalty ridges entered the subduction zone before $2 \mathrm{Ma}$, and resulted in local and regional deformation. The collision of the d'Entrecasteaux Ridge is thought to be responsible for large vertical motions in the central New Hebrides arc [Taylor et al., 1987], as well as initiation of compression in the back-arc area [Collot et al., 1985]. At the southern extremity, the eastern edge of the Loyalty Ridge (cf. Chapter 6, this memoir) entered the subduction zone, which resulted in local flexural uplift of the Loyalty Ridge and southern part of Grande Terre of New Caledonia (cf. Chapter 7, this memoir and Dubois et al. [1974]). This collision is thought to be responsible for initiation of the Matthew Hunter subduction zone along the southern edge of the North Fiji Basin [Monzier et al., 1990; Patriat et al., 2015].

Tectonic impacts on New Caledonian geology 
The geology and present-day shape and structure of New Caledonia are intimately related to the geodynamic evolution of the southwest Pacific. Mesozoic basement terranes, described in Chapter 3 of this memoir, (e.g. Teremba, Boghen and Koh-Central terranes) were deposited and emplaced in the forearc context of the peri-Gondwana subduction zone. Cretaceous to Palaeocene breakup and seafloor spreading between Gondwana and Zealandia resulted in deposition of syn- and post-rift sedimentary cover described in Chapter 4 of this memoir (e.g. Formation à charbon, Black Cherts). Eocene sedimentary rocks found in New Caledonia (e.g. Bourail Group turbidites) along with highpressure low-temperature metamorphic rocks record the reconfiguration of subduction and regional contraction across Zealandia [Sutherland et al., 2017]. Nappe emplacement described in Chapter 5 of this memoir (e.g. Montagnes Blanches Nappe, Poya Nappe and Peridotite Nappe) was associated with the culmination of this tectonic event. Neogene tectonic quiescence reflects Tonga-Kermadec subduction roll-back and isolation of New Caledonia by back-arc basins. During this period, northward motion of the Australian Plate moved New Caledonia to lower latitudes and tropical conditions. These favoured the development of carbonate platforms and deep weathering of exposed rocks described in Chapter 7 of this memoir, notably laterite development on the Peridotite Nappe and formation of supergene nickel ore (cf. Chapter 10, this memoir). Since $2 \mathrm{Ma}$, the southern tip of Grande Terre and the Loyalty Islands, described in Chapter 6 of this memoir, were uplifted by lithospheric flexure associated with subduction at the New Hebrides-Vanuatu trench.

\section{$\underline{\text { Conclusions }}$}

The southwest Pacific contains a diverse assemblage of continents, volcanic arcs, hotspot tracks, large igneous provinces, and oceanic basins. The geodynamic evolution was controlled by the dynamics of subduction zone death, reversal, initiation, and roll-back. This led to the final dispersal of Gondwanaland and formation of the continent of Zealandia. Two classes of plate kinematic model have been proposed to explain development of features since $100 \mathrm{Ma}$. In one class of model, subduction evolution was complex, but nearly continuous throughout the entire period. In the other class of model, subduction ceased in the Late Cretaceous and then re-initiated in the Eocene. The main unresolved plate tectonic issues revolve around arc longevity and polarity in the interval 85-25 Ma that may be better understood by future sampling and analysis in the southwest Pacific.

\section{Acknowledgements}

This work was achieved in the frame of active collaborations between New Caledonia, France, Australia and New Zealand. We acknowledge funding from the Government of New Caledonia, Ifremer and the Australian Research Council through grants FT130101564 and IH130200012. The manuscript was greatly improved by comments from Neville Exon and an anonymous reviewer. We are also very grateful to Editor Nick Mortimer for his significant input in the final version of the manuscript. 


\section{FIGURE CAPTIONS}

Figure 1. (a) New Caledonia in the Southwest Pacific. (b) Bathymetric map of the southwest Pacific [Smith and Sandwell, 1997]. Dashed red line is outline of the Zealandia continent [Mortimer et al., 2017]. (c) Free air gravity anomaly map of the southwest Pacific [Sandwell and Smith, 1997]. Acronyms: Bougainville Seamount (BS); D’Entrecasteaux Ridge (DER); South Rennel Trough (SRT).

Figure 2. Basement geological map of the southwest Pacific, modified after [Collot et al., 2012]

Figure 3. Age of formation of basement of the southwest Pacific, modified after [Collot et al., 2012]. See Figure 2 for legend.

Figure 4. Early Cretaceous plate kinematic reconstruction of Gondwana. Age grids and reconstructions are based on [Müller et al., 2016]. Projection is orthographic, centred on $120^{\circ} /-90^{\circ}$.

Figure 5. Cross sections of two classes of models for the geodynamic evolution of the southwest Pacific. See Fig. 6 for location of cross section.

Figure 6. Map reconstructions of two classes of models for the geodynamic evolution of the southwest Pacific. Paleolatitudes are based on a hotspot reference frame. Red triangles: active volcanic arc. Blue lines: active spreading center. Acronyms: Median Batholith (MB); Loyalty Ridge Three Kings Ridge (LR-3KR); Lau Basin (LB); Lau Colville Ridge (LCR); Tonga Kermadec Ridge (TKR); New Hebrides-Vanuatu arc (NH), North Fiji Basin (NFB). Dashed line indicates location of cross section of Fig. 5. Maps generated with Gplates. 


\section{REFERENCES}

Adams, J. C., D. Cluzel, and W. L. Griffin (2009), Detrital-zircons ages and geochemistry of sedimentary rocks in basement Mesozoic terranes and their cover rocks in New Caledonia, and provenance at the Eastern Gondwanaland margin, Australian Journal of Earth Sciences, 56, 10231047.

Aitchison, J. C., G. L. Clarke, S. Meffre, and D. Cluzel (1995), Eocene arc-continent collision in New Caledonia and implications for regional Southwest Pacific tectonic evolution, Geology, 23(2), 161-164.

Auzende, J.-M., B. Pelletier, and J.-P. Eissen (1995a), The North Fiji Basin Geology, Structure, and Geodynamic Evolution, in Backarc Basins: Tectonics and Magmatism, edited by B. Taylor, pp. 139-175, Springer US, Boston, MA.

Auzende, J.-M., J. P. Rissen, Y. Lafoy, P. Gente, and J. L. Charlou (1988a), Seafloor spreading in the North Fiji Basin (Southwest Pacific), Tectonophysics, 146, 317-351.

Auzende, J. M., Y. Lafoy, and B. Marsset (1988b), Recent geodynamic evolution of the North Fiji basin (southwest Pacific), Geology, 16, 925-929.

Auzende, J. M., R. N. Hey, B. Pelletier, D. Rouland, Y. Lafoy, E. Gracia, and P. Huchon (1995b), Propagating rift west of the Fiji archipelago (North Fiji Basin, SW Pacific), Journal of Geophysical Research - Solid Earth, 100(B9), 17823-17835.

Bache, F., R. Sutherland, V. Stagpoole, R. H. Herzer, J. Collot, and P. Rouillard (2012), Stratigraphy of the southern Norfolk Ridge and the Reinga Basin: a record of initiation of TongaKermadec-Northland subduction in the southwest Pacific, Earth and Planetary Science Letters, 321323, 41-53.

Bache, F., N. Mortimer, R. Sutherland, J. Collot, P. Rouillard, V. Stagpoole, and A. Nicol (2013), Seismic stratigraphic record of transition from Mesozoic subduction to continental breakup in the Zealandia sector of eastern Gondwana, Gondwana Research(0).

Ballance, P. F. (1999), Simplification of the Southwest Pacific Neogene arcs: inherited complexity and control by a retreating pole of rotation, The Geological Society of London.

Ballance, P. F., and K. B. Sporli (1979), Northland Allochthon, Journal of the Royal Society of New Zealand, 9(2), 259-275.

Ballance, P. F., J. R. Pettinga, and C. Webb (1982), A model of the Cenozoic evolution of northern New Zealand and adjacent areas of the southwest Pacific, Tectonophysics, 87(1-4), 37-48.

Bergeot, N., M. N. Bouin, M. Diament, P. Pelletier, M. Regnier, S. Calmant, and V. Ballu (2009), Horizontal and vertical interseismic velocity fields in the Vanuatu subduction zone from GPS measurements: Evidence for a central Vanuatu locked zone, Journal of Geophysical Research - Solid Earth, 114(B06405).

Bevis, M., F. W. Taylor, B. E. Schutz, J. Recy, B. L. Isacks, S. Helu, R. Singh, E. Kendrick, J. Stowell, B. Taylor, and S. Calmant (1995), Geodetic observations of very rapid convergence and backarc extension at the Tonga Arc, Nature, 374(6519), 249-251.

Bloomer, S. H., B. Taylor, C. J. MacLeod, R. J. Stern, P. Fryer, J. W. Hawkins, and L. Johnson (1995), Early arc volcanism and the ophiolite problem: A perspective from drilling in the western Pacific, in Active Margins and Marginal Basins of the western, in Pacific Geophysical Monograph Series, edited by B. Taylor and J. Natlan, pp. 1-30, AGU, Washington D.C.

Bradshaw, J. D. (1981), Mesozoic accretion of exotic terranes along the New-Zealand segment of gondwanaland - comment, Geology, 9(3), 100-\&.

Brocher, T. M. (1985), On the formation of the Vitiaz Trench lineament and North Fiji Basin, Circum-Pacific Council for Energy and Mineral Resources, Earth Science Series, Houston, Texas.

Buys, J., C. Spandler, R. J. Holm, and S. W. Richards (2014), Remnants of ancient Australia in Vanuatu: Implications for crustal evolution in island arcs and tectonic development of the southwest Pacific, Geology, 42(11), 939-942. 
Calmant, S., B. Pelletier, P. Lebellegard, M. Bevis, F. W. Taylor, and D. A. Phillips (2003), New insights on the tectonics along the New Hebrides subduction zone based on GPS results, Journal of Geophysical Research - Solid Earth, 108(B6).

Carter, R. M., L. Carter, and B. Davy (1992), Seismic stratigraphy of the bounty trough, southwest Pacific Ocean, Marine and Petroleum Geology, 11(1), 79-93.

Chase, C. G. (1971), Tectonic history of the Fiji plateau, Geological Society of America Bulletin, 82, 3087-3110.

Cluzel, D., J. C. Aitchison, and C. Picard (2001), Tectonic accretion and underplating of mafic terranes in the late Eocene intraoceanic fore-arc of New Caledonia (Southwest Pacific): geodynamic implications, Tectonophysics, 340(1/2), 23-59.

Cluzel, D., S. Meffre, P. Maurizot, and A. J. Crawford (2006), Earliest Eocene (53 Ma) convergence in the Southwest Pacific: evidence from pre-obduction dikes in the ophiolite of New Caledonia, Terra Nova, 18(6), 395-402.

Cluzel, D., P. M. Black, C. Picard, and K. N. Nicholson (2010a), Geochemistry and tectonic setting of Makatoa Volcanics, East Coast Allochthon, New Zealand: :Suprasubduction zone affinity, regional correlations, and origin, Tectonics, 29(TC2013), 1-21.

Cluzel, D., P. Maurizot, J. Collot, and B. Sevin (2012a), An outline of the Geology of New Caledonia ; from Permian - Mesozoic Southeast Gondwanaland active margin to Cenozoic obduction and supergene, Episodes, 72-86.

Cluzel, D., J. C. Adams, S. Meffre, H. Campbell, and P. Maurizot (2010b), Discovery of Early Cretaceous rocks in New Caledonia; new geochemical and U-Pb zircon age constraints on the transition from subduction to marginal breakup in the Southwest Pacific, The Journal of Geology, 118(4), 381-397.

Cluzel, D., F. Jourdan, S. Meffre, P. Maurizot, and S. Lesimple (2012b), The metamorphic sole of New Caledonia ophiolite:40Ar/39Ar, U-Pb, and geochemical evidence for subduction inception at a spreading ridge, Tectonics, 31(3), n/a-n/a.

Cluzel, D., M. Whitten, S. Meffre, J. C. Aitchison, and P. Maurizot (2018), A Reappraisal of the Poya Terrane (New Caledonia): Accreted Late Cretaceous-Paleocene Marginal Basin Upper Crust, Passive Margin Sediments, and Early Eocene E-MORB Sill Complex, Tectonics.

Cluzel, D., M. Ulrich, F. Jourdan, S. Meffre, J.-L. Paquette, M.-A. Audet, A. Secchiari, and P. Maurizot (2016), Early Eocene clinoenstatite boninite and boninite-series dikes of the ophiolite of New Caledonia; a witness of slab-derived enrichment of the mantle wedge in a nascent volcanic arc, Lithos, 260, 429-442.

Collot, J., R. H. Herzer, Y. Lafoy, and L. Géli (2009), Mesozoic history of the Fairway - Aotea Basin: implications regarding the early stages of Gondwana fragmentation, Geochemistry Geophysics Geosystems, 10(Q12019), doi: 10.1029/2009GC002612.

Collot, J., M. Vende-Leclerc, P. Rouillard, Y. Lafoy, and L. Géli (2012), Map helps unravel complexities of the Southwestern Pacific Ocean, Eos Transactions of American Geophysical Union, 93(1), 1-2.

Collot, J., G. Lamarche, R. A. Wood, J. Delteil, M. Sosson, J.-F. Lebrun, and M. F. Coffin (1995), Morphostructure of an incipient subduction zone along a transform plate boundary: Puysegur Ridge and Trench, Geology, 23(6), 519-522.

Collot, J. Y., J. Daniel, and R. V. Burne (1985), Recent tectonics associated with the subduction / collision of the d'Entrecastreaux zone in the central New Hebrides, Tectonophysics, 112, 325-356.

Collot, J. Y., S. Lallemand, B. Pelletier, J. P. Eissen, G. Glacon, M. A. Fisher, H. G. Greene, J. Boulin, J. Daniel, and M. Monzier (1992), Geology of the d'Entrecasteaux - New Hebrides arc collision zone - results from a deep submersible survey, Tectonophysics, 212(3-4), 213-241.

Crawford, A. J., S. Meffre, and P. A. Symonds (2003a), 120 to 0 Ma tectonic evolution of the southwest pacific and analogous geological evolution of the 600 to 220 Ma Tasman Fold Belt System, Geological Society of Australia Special Publication, 22, 377-397. 
Crawford, W. C., J. A. Hildebrand, L. M. Dorman, S. C. Webb, and D. A. Wiens (2003b), Tonga ridge and Lau Basin crustal structure from seismic refraction data, Journal of Geophysical Research Solid Earth, 108(B4).

Dallanave, E., C. Agnini, K. M. Pascher, P. Maurizot, V. Bachtadse, C. J. Hollis, G. R. Dickens, J. Collot, and E. Monesi (2018), Magneto-biostratigraphic constraints of the Eocene micritecalciturbidite transition in New Caledonia: tectonic implications, New Zealand Journal of Geology and Geophysics, 61(2), 145-163.

Davey, F. J. (1982), The structure of the South Fiji Basin, Paleomagnetism, global tectonics and the rock record, 87(1-4), 185-241.

Davy, B. W., K. Hoernle, and R. Werner (2008), Hikurangi Plateau : crustal structure, rifted formation, and Gondwana subduction history, Geochemistry Geophysics Geosystems, 9(7), Q07004, doi:07010.01029/02007GC001855.

Dubois, J., J. Launay, and J. Recy (1974), Uplift movements in New Caledonia-Loyalty Islands area and their plate tectonics interpretation, Tectonophysics, 24(1-2), 133-150.

Dubois, J., J. Launay, J. Recy, and J. F. Marshall (1977), New Hebrides trench: subduction rate from associated lithospheric buldge, Can. J. Earth. Sci., 14, 250-255.

Duncan, R. A., T. L. Vallier, and D. A. Falvey (1985), Volcanic episode at 'Eua, Tonga Islands, Circum-Pacific Council Energy Mineral Resource Earth Science Series, Houston, Texas.

Eissen, J.-P., A. J. Crawford, J. Cotten, S. Meffre, H. Bellon, and M. Delaune (1998), Geochemistry and tectonic significance of basalts in the Poya Terrane, New Caledonia, Tectonophysics, 284(3-4), 203-219.

Etienne, S., J. Collot, R. Sutherland, M. Patriat, F. Bache, P. Rouillard, S. Henrys, D. Barker, and C. Juan (2017), Deepwater sedimentation and Cenozoic deformation in the Southern New Caledonia Trough (Northern Zealandia, SW Pacific), Marine Petroleum Geology, 92, 764-779, doi: 10.1016/j.marpetgeo.2017.12.007.

Falvey, D. A. (1975), Arc reversals, and a tectonic model for the North Fiji Basin, Australian Society of Exploration Geophysical Bull., 6, 47-49.

Gaina, C., D. R. Mueller, J.-Y. Royer, J. Stock, J. L. Hardebeck, and P. Symonds (1998), The tectonic history of the Tasman Sea: a puzzle with 13 pieces, Journal of Geophysical Research - Solid Earth, 103(6), 12,413-412,433.

Gill, J. B. (1987), Early Geochemical Evolution of an Oceanic Island Arc and Backarc: Fiji and the South Fiji Basin, The Journal of Geology, 95(5), 589-615.

Greene, H. G., J. Y. Collot, and L. B. Stokking (1994), Proc. ODP, Sci. Results, 134, College Station, TX (Ocean Drilling Program), doi: 10.2973/odp.proc.sr.134.1994.

Gurnis, M., C. E. Hall, and L. L. Lavier (2004), Evolving force balance during incipient subduction, Geochemistry Geophysics Geosystems, 5, Q07001, doi:07010.01029/02003GC000681.

Hall, R. (2002), Cenozoic geological and plate tectonic evolution of SE Asia and the SW Pacific: Computer-based reconstructions, model and animations, Journal Asian Earth Science, 20, 353-431.

Hall, R., and W. Spakman (2002), Subducted slabs beneath the eastern Indonesia-Tonga region: insights from tomography, Earth and Planetary Science Letters, 201(2), 321-336.

Hawkins, J. W. (1995), Evolution of the Lau Basin - insights from ODP Leg 135, in Active Margins and Marginal Basins of the Western Pacific - Geophysical Monograph, edited by AGU. Hayes, D. E., and J. Ringis (1973), Seafloor Spreading in the Tasman Sea, Nature (London), 244(5408), 454-458.

Herzer, R. H., D. Barker, W. Roest, and N. Mortimer (2011), Oligocene-Miocene spreading history of the northern South Fiji Basin and implications of the New Zealand plate boundary, Geochemistry Geophysics Geosystems, 12(2).

Herzer, R. H., G. C. H. Chaproniere, A. R. Edwards, C. J. Hollis, B. Pelletier, J. I. Raine, G. H. Scott, V. Stagpoole, C. P. Strong, P. Symonds, G. J. Wilson, and H. Zhu (1997), Seismic stratigraphy and structural history of the Reinga Basin and its margins southern Norfolk Ridge system, New Zealand Journal of Geology and Geophysics, 40, 425-451. 
Heuret, A., and S. Lallemand (2005), Plate motions, slab dynamics and back-arc deformation, Physics of The Earth and Planetary Interiors, 149(1-2), 31-51.

Karig, D. E. (1971), Origin and development of marginal basins in the western Pacific, Journal of Geophysical Research - Solid Earth, 76, 2542-2561.

Klingelhoefer, F., Y. Lafoy, J. Collot, E. Cosquer, L. Géli, H. Nouzé, and R. Vially (2007), Crustal structure of the basin and ridge system west of New Caledonia (southwest Pacific) from wide-angle and reflection seismic data, Journal of Geophysical Research - Solid Earth, 112(B11102).

Knesel, K. M., B. E. Cohen, P. M. Vasconcelos, and D. S. Thiede (2008), Rapid change in drift of the Australian plate records collision with Ontong Java plateau, Nature, 454, 754-758.

Kroenke, L. W. (1984), Cenozoic tectonic development of the Southwest Pacific, Technical Bulletin - United Nations, Economic and Social Commission for Asia and the Pacific (ESCAP). Committee for Co-ordination of Joint Prospecting for Mineral Resources in South Pacific Offshore Areas, 6(126).

Lafoy, Y., B. Pelletier, J. M. Auzende, F. Missègue, and L. Mollard (1994), Tectonique compressive cénozoïque sur les rides de Fairway et Lord Howe, entre Nouvelle Calédonie et Australie, Comptes rendus de l'Académie des sciences, Série II, Sciences de la terre et des planètes, 319, 1063-1069.

Laird, M. G. (1992), Geological aspects of the opening of the Tasman Sea, Geological Society of New Zealand Miscellaneous Publication, 63A, 86-87.

Lamarche, G., and J.-F. Lebrun (2000), Transition from strike-slip faulting to oblique subduction: active tectonics at the Puysegur Margin, South New Zealand, Tectonophysics, 316(1), 6789.

Li, P. F., G. Rosenbaum, and D. Rubatto (2012), Triassic asymmetric subduction rollback in the southern New England Orogen (eastern Australia): the end of the Hunter-Bowen Orogeny, Australian Journal of Earth Sciences, 59(6), 965-981.

Luyendyk, B. P., D. S. Wilson, and C. S. Siddoway (2003), Eastern margin of the Ross Sea Rift in western Marie Byrd Land, Antarctica: Crustal structure and tectonic development, Geochemistry, Geophysics, Geosystems, 4(10), n/a-n/a.

Luyendyk, B. P., C. C. Sorlien, D. S. Wilson, L. R. Bartek, and C. S. Siddoway (2001), Structural and tectonic evolution of the Ross Sea rift in the Cape Colbeck region, Eastern Ross Sea, Antarctica, Tectonics, 20(6), 933-958.

Maillet, P., M. Monzier, M. Selo, and D. Storzer (1983), The d'Entrecasteaux Zone (Southwest pacific) - a petrological and geochronological reappraisal, Marine Geology, 53(3), 179-197.

Malahoff, A., R. H. Feden, and H. S. Fleming (1982), Magnetic anomalies and tectonic fabric of marginal basins north of New Zealand, Journal of Geophysical Research - Solid Earth, 87(5), 41094125.

Malpas, J., K. B. Spörli, M. P. Black, and I. E. M. Smith (1992), Northland ophiolite, New Zealand, and implications for plate-tectonic evolution of the southwest Pacific, Geology, 20(2), 149152.

Matthews, K. J., M. Seton, and R. D. Müller (2012), A global-scale plate reorganization event at 105-100Ma, Earth and Planetary Science Letters, 355-356(Supplement C), 283-298.

Matthews, K. J., S. E. Williams, J. M. Whittaker, R. D. Müller, M. Seton, and G. L. Clarke (2015), Geologic and kinematic constraints on Late Cretaceous to mid Eocene plate boundaries in the southwest Pacific, Earth-Science Reviews, 140(0), 72-107.

Mauffret, A., P. A. Symonds, S. Meffre, L. J. Carson, and G. Bernardel (2002), Geological and morphological framework of the Norfolk Ridge to Three Kings Ridge Region: the FAUST-2 Survey Area, Geoscience Australia Record, 2002/008.

Maurizot, P. (2012), The Adio limestones (New Caledonia): from a passive to an active margin in the northern Norfolk Ridge during Paleocene, New Zealand Journal of Geology and Geophysics, 56, 16-26.

McDougall, I., and R. A. Duncan (1988), Age progressive volcanism in the Tasmantid Seamounts, Earth and Planetary Science Letters, 89(2), 207-220. 
McDougall, I., B. J. J. Embleton, and D. B. Stone (1981), Origin and evolution of Lord Howe Island, Southwest Pacific, Journal of the Geological Society of Australia, 28, 155-176.

McDougall, I., J. W. Hawkins, L. Parson, and J. Allan (1994), Data report: Dating of rhyolitic glass in the Tonga forearc (Hole 841B), in Proceedings of the Ocean Drilling Program, Scientific Results, edited.

Meffre, S., T. J. Falloon, T. J. Crawford, K. Hoernle, F. Hauff, R. A. Duncan, S. H. Bloomer, and D. J. Wright (2012), Basalts erupted along the Tongan fore arc during subduction initiation: Evidence from geochronology of dredged rocks from the Tonga fore arc and trench, Geochemistry, Geophysics, Geosystems, 13(12).

Miles, P., M. Pubellier, and J. Collot (2016), Structural Map of the Western Pacific Ocean at 1:20000 000 scale, CCGM-CGMW.

Missègue, F., and J. Y. Collot (1987), Etude géophysique du plateau des Chesterfield (Pacifique Sud-Ouest) - Résultat préliminaires de la campagne ZOE 200 du N/O Coriolis, Comptes Rendus de l'Académie des Sciences, Série 2, 279-283.

Monzier, M., J. Daniel, and P. Maillet (1990), La collision Ride des Loyautés / arc des Nouvelles-Hébrides (Pacifique Sud-Ouest), Oceanological Acta, 10.

Mortimer, N. (2004), Basement gabbro from the Lord Howe Rise, New Zealand Journal of Geology and Geophysics, 47, 501-507.

Mortimer, N., F. Hauff, and A. T. Calvert (2008), Continuation of the New England Orogen, Australia, beneath the Queensland Plateau and Lord Howe Rise, Australian Journal of Earth Sciences, 55, 195-209.

Mortimer, N., J. I. Raine, and R. A. Cook (2009), Correlation of basement rocks from Waka Nui-1 and Awhitu-1, and the Jurassic regional geology of Zealandia, New Zealand Journal of Geology and Geophysics, 52(1), 1-10.

Mortimer, N., R. H. Herzer, P. B. Gans, D. L. Parkinson, and D. Seward (1998), Basement geology from Three Kings Ridge to West Norfolk Ridge, Southwest Pacific Ocean; evidence from petrology, geochemistry and isotopic dating of dredge samples, Marine Geology, 148(3-4), 135-162.

Mortimer, N., F. J. Davey, A. Melhuish, J. Yu, and N. J. Godfrey (2002), Geological interpretation of a deep seismic reflection profile across the Eastern Province and Median Batholith, New Zealand: crustal architecture of an extended Phanerozoic convergent orogen, New Zealand Journal of Geology and Geophysics, 45, 349-363.

Mortimer, N., R. H. Herzer, N. W. Walker, A. T. Calvert, D. Seward, and G. C. H. Chaproniere (2003), Cavalli Seamount, Northland Plateau, SW Pacific Ocean: a Miocene metamorphic core complex?, Journal of the Geological Society, 160(6), 971-983.

Mortimer, N., R. H. Herzer, P. B. Gans, C. Laporte-Magoni, A. T. Calvert, and D. Bosch (2007), Oligocene-Miocene tectonic evolution of the South Fiji Basin and Northland Plateau, SW Pacific Ocean: evidence from petrology and dating of dredged rocks, Marine Geology, 237, 1-24.

Mortimer, N., P. B. Gans, J. M. Palin, R. H. Herzer, B. Pelletier, and M. Monzier (2014), Eocene and Oligocene basins and ridges of the Coral Sea-New Caledonia region: Tectonic link between Melanesia, Fiji, and Zealandia, Tectonics, 33(7), 1386-1407.

Mortimer, N., A. J. Tulloch, R. N. Spark, N. W. Walker, E. Ladley, A. Allibone, and D. L. Kimbrough (1999), Overview of the Median Batholith, New Zealand; a new interpretation of the geology of the Median Tectonic Zone and adjacent rocks, Journal of African Earth Sciences, 29(1), 257-268.

Mortimer, N., H. Campbell, A. J. Tulloch, P. R. King, V. Stagpoole, R. A. Wood, M. S. Rattenbury, R. Sutherland, C. J. Adams, J. Collot, and M. Seton (2017), Zealandia: Earth's hidden continent, GSA Today, 27(3), 27-35, doi: 10.1130/GSATG321A.1.

Mortimer, N., P. B. Gans, S. Meffre, C. E. Martin, M. Seton, S. Williams, R. E. Turnbull, P. G. Quilty, S. Micklethwaite, C. Timm, R. Sutherland, F. Bache, J. Collot, P. Maurizot, P. Rouillard, and N. Rollet (2018), Regional volcanism of northern Zealandia: post-Gondwana break-up magmatism on an extended, submerged continent, in Large Igneous Provinces from Gondwana and Adjacent Regions, edited by S. Sensarma and B. C. Storey, pp. 199-226, Geological Society, London, Special Publications. 
Muir, R. J., S. D. Weaver, J. D. Bradshaw, G. N. Eby, and J. A. Evans (1995), The Cretaceous Separation Point batholith, New Zealand: granitoid magmas formed by melting of mafic lithosphere, Journal of the Geological Society, 152(4), 689-701.

Müller, R. D., C. Gaina, A. Tikku, D. Mihut, S. C. Cande, and J. Stock (2000), Mesozoic/Cenozoic tectonic events around Australia, in The History of Dynamics of Global Motions Geophysical Monograph, edited by A. G. Union, pp. 161-188, Washington DC.

Müller, R. D., M. Seton, S. Zahirovic, S. E. Williams, K. J. Matthews, N. M. Wright, G. E. Shephard, K. T. Maloney, N. Barnett-Moore, M. Hosseinpour, D. J. Bower, and J. Cannon (2016), Ocean Basin Evolution and Global-Scale Plate Reorganization Events Since Pangea Breakup, Annual Review of Earth and Planetary Sciences, 44(1), 107-138.

Nicholson, K. N., P. M. Black, and C. Picard (2000a), Geochemistry and tectonic significance of the Tangihua Ophiolite Complex, New Zealand, Tectonophysics, 321(1), 1-15.

Nicholson, K. N., C. Picard, and P. M. Black (2000b), A comparative study of Late Cretaceous ophiolitic basalts from New Zealand and New Caledonia: implications for the tectonic evolution of the SW Pacific, Tectonophysics, 327(3-4), 157-171.

Nicholson, K. N., P. M. Black, and K. B. Sporli (2008), Cretaceous-Oligocene multiphase magmatism on Three Kings Islands, northern New Zealand, New Zealand Journal of Geology and Geophysics, 51(3), 219-229.

Norvick, M. S., R. P. Langford, T. Hashimoto, N. Rollet, K. L. Higgins, and M. P. Morse (2008), New insights into the evolution of the Lord Howe Rise (Capel and Faust basins), offshore eastern Australia, from terrane and geophysical data analysis, PESA Eastern Australasian Basins Symposium III, Sydney, 14-17 September, 2008, 291-310.

O'Connor, J. M., B. Steinberger, M. Regelous, A. A. P. Koppers, J. R. Wijbrans, K. M. Haase, P. Stoffers, W. Jokat, and D. Garbe-Schönberg (2013), Constraints on past plate and mantle motion from new ages for the Hawaiian-Emperor Seamount Chain, Geochemistry, Geophysics, Geosystems, 14(10), 4564-4584.

Parson, L. M., and I. C. Wright (1996), The Lau-Havre-Taupo back-arc basin: A southwardpropagating, multi-stage evolution from rifting to spreading, Tectonophysics, 263(1-4), 1-22.

Patriat, M., J. Collot, L. Danyushevsky, M. Fabre, S. Meffre, T. Falloon, P. Rouillard, B. Pelletier, M. Roach, and M. Fournier (2015), Propagation of back-arc extension into the arc lithosphere in the southern New Hebrides volcanic arc, Geochemistry Geophysics Geosystems, 16(9), 3142-3159.

Pelletier, B. (2007), Geology of the New Caledonia region and its implications for the study of the New Caledonian biodiversity, in Compendium of marines species from New Caledonia - Forum Biodiversité des Ecosystèmes Coralliens, edited by C. P. a. B. R. d. F. Edts, pp. 17-30, IRD, Nouméa. Pelletier, B., and R. Louat (1989), Mouvements relatifs des plaques dans le Sud-Ouest Pacifique, Comptes Rendus de l'Academie des Sciences, Series 2, 308(1), 123-130.

Pelletier, B., and J. M. Auzende (1996), Geometry and structure of the Vitiaz trench lineament (SW Pacific), Marine Geophysical Researches, 18, 305-335.

Pelletier, B., S. Calmant, and R. Pillet (1998), Current tectonics of the Tonga New Hebrides region, Earth and Planetary Science Letters, 164(1-2), 263-276.

Pelletier, B., Y. Lagabrielle, M. Benoit, G. Cabioch, S. Calmant, E. Garel, and C. Guivel (2001), Newly identified segments of the Pacific-Australia plate boundary along the North Fiji transform zone, Earth and Planetary Science Letters, 193(3-4), 347-358.

Petterson, M. G., T. Babbs, C. R. Neal, J. J. Mahoney, A. D. Saunders, R. A. Duncan, D. Tolia, R. Magu, C. Qopoto, H. Mahoa, and D. Natogga (1999), Geological-tectonic framework of Solomon Islands, SW Pacific: crustal accretion and growth within an intra-oceanic setting, Tectonophysics, 301(1-2), 35-60.

Pirard, C., and C. Spandler (2017), The zircon record of high-pressure metasedimentary rocks of New Caledonia: Implications for regional tectonics of the south-west Pacific, Gondwana Research, 46, 79-94. 
Richards, M. A., and C. Lithgow-Bertelloni (1996), Plate motion changes, the HawaiianEmperor bend, and the apparent success and failure of geodynamic models, Earth and Planetary Science Letters, 137(1-4), 19-27.

Rouillard, P., J. Collot, R. Sutherland, F. Bache, M. Patriat, S. Etienne, and P. Maurizot (2017), Seismic stratigraphy and paleogeographic evolution of Fairway Basin, Northern Zealandia, Southwest Pacific: from Cretaceous Gondwana breakup to Cenozoic Tonga-Kermadec subduction, Basin Research, 29, 189-212.

Ruohong, J., S. Diane, L. T. A., and K. B. P. (2014), Thermal history and exhumation of basement rocks from Mesozoic to Cenozoic subduction cycles, central North Island, New Zealand, Tectonics, 33(10), 1920-1935.

Sandwell, D. T., and W. H. Smith (1997), Marine gravity anomaly from Geosat and ERS 1 satellite altimetry, Journal of Geophysical Research - Solid Earth, 102(B5), 10039-10054.

Schellart, W. P., G. S. Lister, and V. G. Toy (2006), A Late Cretaceous and Cenozoic reconstruction of the Southwest Pacific region: Tectonics controlled by subduction and slab rollback processes, Earth Science Reviews, 76(3-4), 191-233.

Sdrolias, M., R. Müller, and C. Gaina (2001), Plate tectonic evolution of eastern Australian marginal ocean basins, paper presented at Eastern Australian Basins Symposium.

Sdrolias, M., R. Müller, and C. Gaina (2003), Tectonic evolution of the southwest Pacific using constraints from backarc basins, Geological Society of America Special Papers, 372, 343-359.

Seton, M., N. Mortimer, S. Williams, P. Quilty, P. Gans, S. Meffre, S. Micklethwaite, S. Zahirovic, J. Moore, and K. J. Matthews (2016), Melanesian back-arc basin and arc development: Constraints from the eastern Coral Sea, Gondwana Research, 39, 77-95.

Smith, W. H. F., and D. T. Sandwell (1997), Global sea floor topography from satellite altimetry and ship depth soundings, Science, 277(5334), 1956-1962.

Steinberger, B., R. Sutherland, and R. J. O'Connell (2004), Prediction of Emperor-Hawaii seamount locations from a revised model of global plate motion and mantle flow, Nature, 430, 167173.

Sutherland, R. (1999), Basement geology and tectonic development of the greater New Zealand region: an interpretation from regional magnetic data, Tectonophysics, 308(3), 341-362.

Sutherland, R., F. Davey, and J. Beavan (2000), Plate boundary deformation in South Island, New Zealand, is related to inherited lithospheric structure, Earth and Planetary Science Letters, $177(3), 141-151$.

Sutherland, R., M. Gurnis, P. J. J. Kamp, and M. A. House (2009), Regional exhumation history of brittle crust during subduction initiation, Fiordland, southwest New Zealand, and implications for thermochronologic sampling and analysis strategies, Geosphere, 5(5), 409-425.

Sutherland, R., J. Collot, Y. Lafoy, G. A. Logan, R. Hackney, V. Stagpoole, C. Uruski, T. Hashimoto, K. Higgins, R. H. Herzer, R. Wood, N. Mortimer, and N. Rollet (2010), Lithosphere delamination with foundering of lower crust and mantle caused permanent subsidence of New Caledonia Trough and transient uplift of Lord Howe Rise during Eocene and Oligocene initiation of Tonga-Kermadec subduction, western Pacific, Tectonics, 29(2), n/a-n/a, doi: 10.1029/2009tc002476.

Sutherland, R., J. Collot, F. Bache, S. Henrys, D. Barker, G. H. Browne, M. J. F. Lawrence, H. Morgans, C. J. Hollis, C. Clowes, N. Mortimer, P. Rouillard, M. Gurnis, S. Etienne, and W. Stratford (2017), Widespread compression associated with Eocene Tonga-Kermadec subduction initiation, Geology, 45(4), 355-358, doi: 10.1130/G38617.1.

Taylor, B., C. Frohlich, J. Lecolle, and M. Strecker (1987), Analysis of partially emerged corals and reef terraces in the central Vanuatu Arc: Comparison of contemporary coseismic and nonseismic with quaternary vertical movements, Journal of Geophysical Research: Solid Earth, 92(B6), 49054933.

Taylor, B., K. Zellmer, F. Martinez, and A. Goodliffe (1996), Sea-floor spreading in the Lau back-arc basin, Earth and Planetary Science Letters, 144(1), 35-40. 
Tulloch, A. J., J. Ramezani, N. Mortimer, J. Mortensen, P. van den Bogaard, and R. Maas (2009), Cretaceous felsic volcanism in New Zealand and Lord Howe Rise (Zealandia) as a precursor to final Gondwana break-up, Geological Society, London, Special Publications, 321(1), 89-118.

Ulrich, M., C. Picard, S. Guillot, C. Chauvel, D. Cluzel, and S. Meffre (2010), Multiple melting stages and refertilization as indicators for ridge to subduction formation: The New Caledonia ophiolite, Lithos, 115(1), 223-236.

Van der Lingen, G. J., J. E. Andrews, R. E. Burns, M. Churkin, Jr., T. A. Davies, P. Dumitrica, A. R. Edwards, J. S. Galehouse, J. P. Kennett, and G. H. Packham (1973), Lithostratigraphy of Eight Drill Sites in the South-west Pacific; Preliminary Results of Leg 21 of the Deep Sea Drilling Project.;

Oceanography of the South Pacific 1972, 299-313.

van der Meer, Q. H. A., M. Storey, J. M. Scott, and T. E. Waight (2016), Abrupt spatial and geochemical changes in lamprophyre magmatism related to Gondwana fragmentation prior, during and after opening of the Tasman Sea, Gondwana Research.

Veevers, J. J. (2000), Change of tectono-stratigraphic regime in the Australian plate during the $99 \mathrm{Ma}$ (mid-Cretaceous) and $43 \mathrm{Ma}$ (mid-Eocene) swerves of the Pacific, Geology, 28(1), 47-50. Watts, A. B., J. K. Weissel, and R. L. Larson (1977), Sea-floor spreading in marginal basins of Western Pacific, Tectonophysics, 37(1-3), 167-181.

Whattam, S. A., J. Malpas, J. R. Ali, and I. E. Smith (2008), New SW Pacific tectonic model: Cyclical intraoceanic magmatic arc construction and near-coeval emplacement along the AustraliaPacific margin in the Cenozoic, Geochemistry Geophysics Geosystems, 9(3).

Williams, S. E., J. M. Whittaker, and R. D. Müller (2011), Full-fit, palinspastic reconstruction of the conjugate Australian-Antarctic margins, Tectonics, 30(6), n/a-n/a.

Yan, C. Y., and L. W. Kroenke (1993), A Plate tectonic reconstruction of the SouthWest Pacific, 0-100 Ma, Proceedings of the Ocean Drilling Program, Scientific Results, 130, 697-707. 


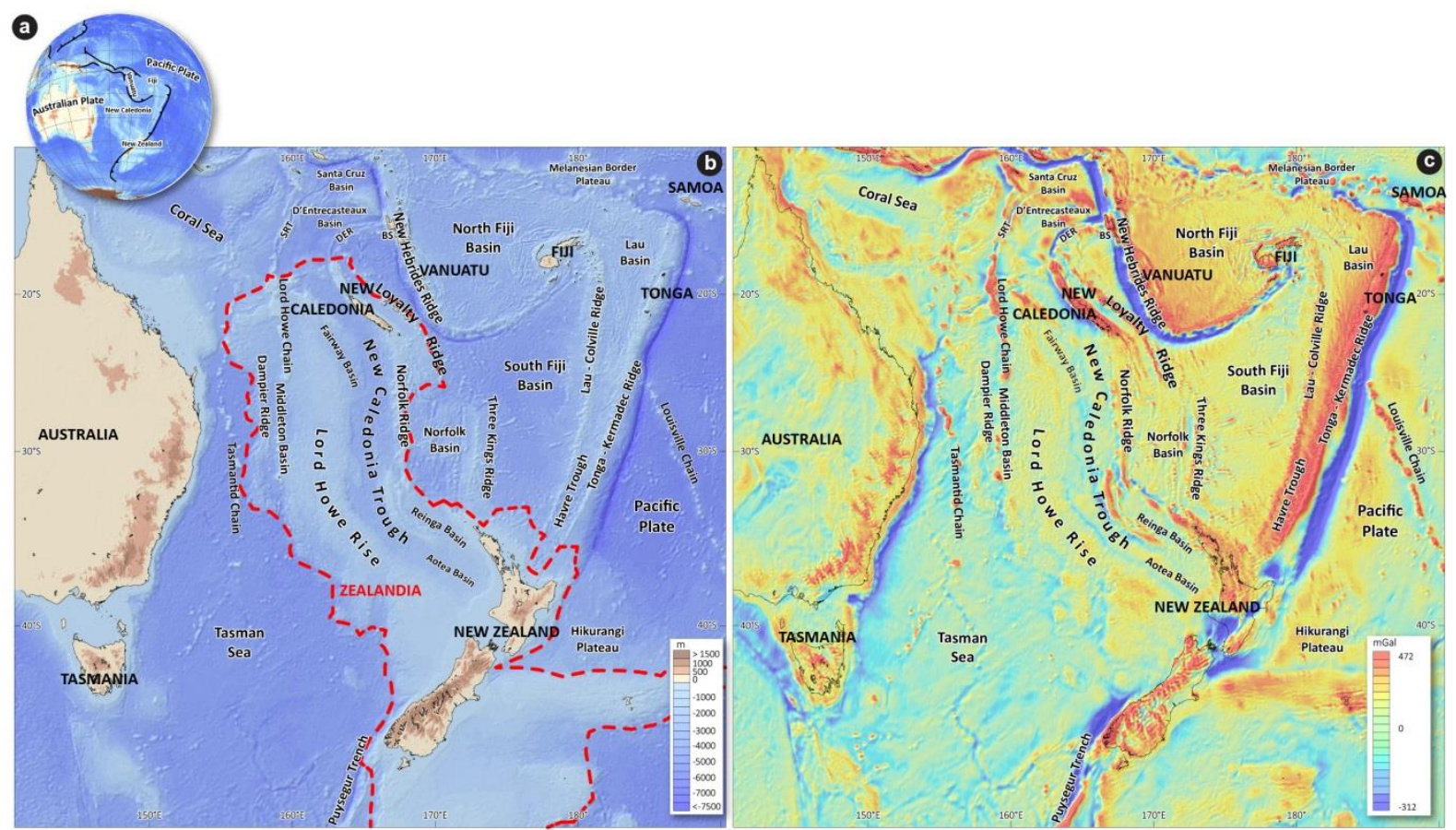

Figure 1 


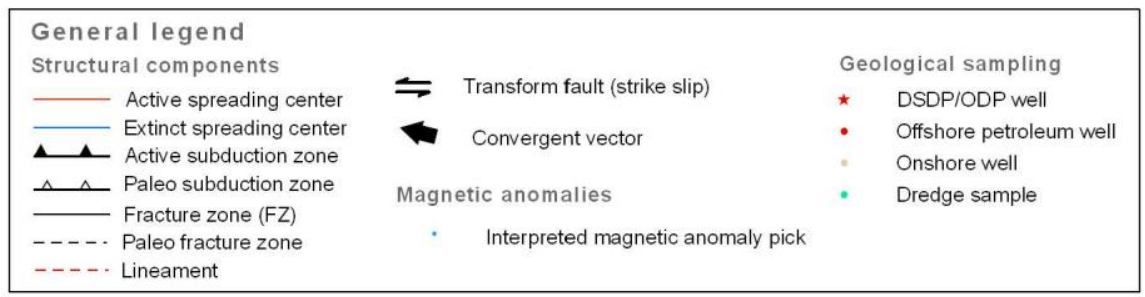

Figure 2 


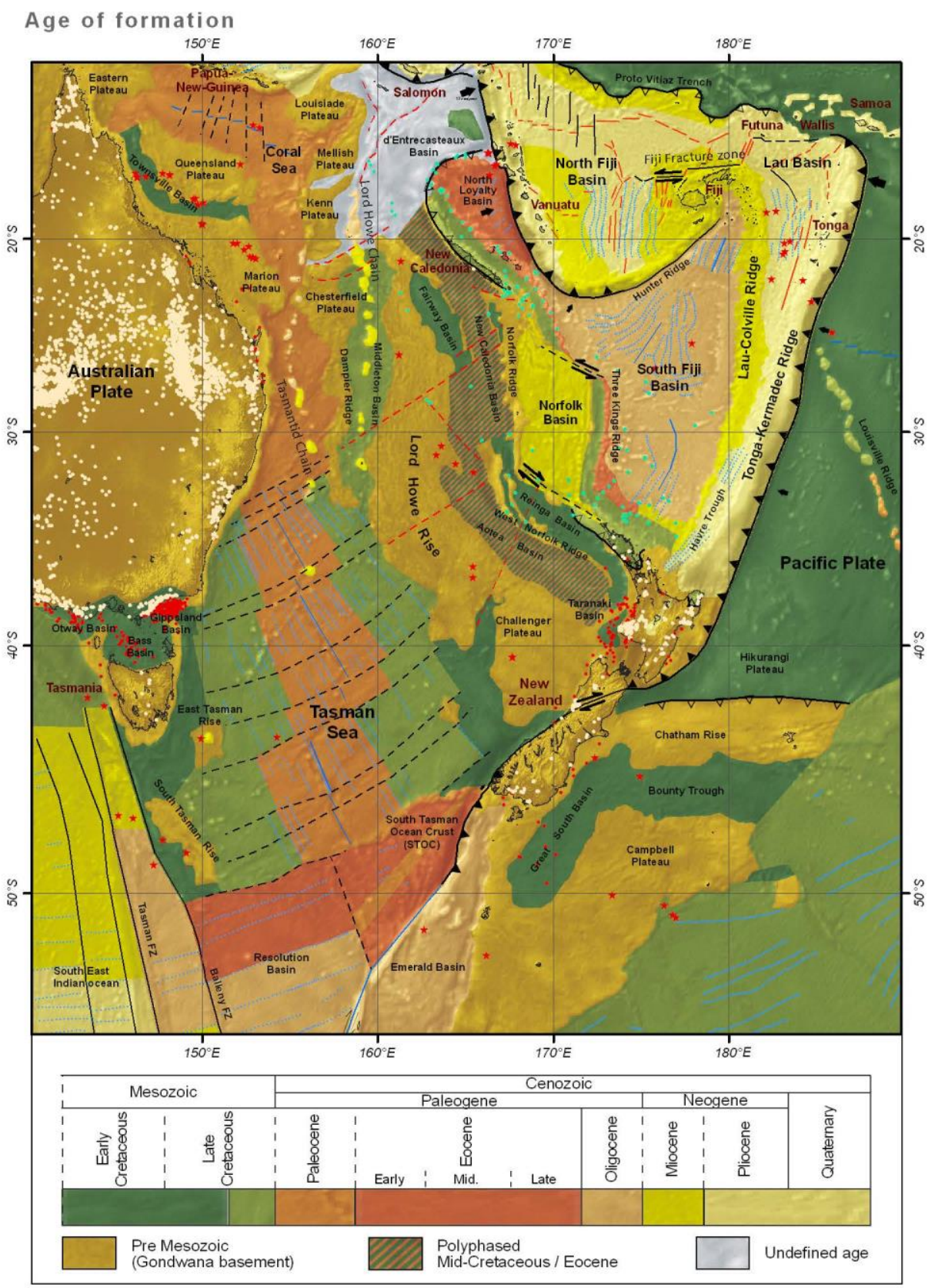

Figure 3 


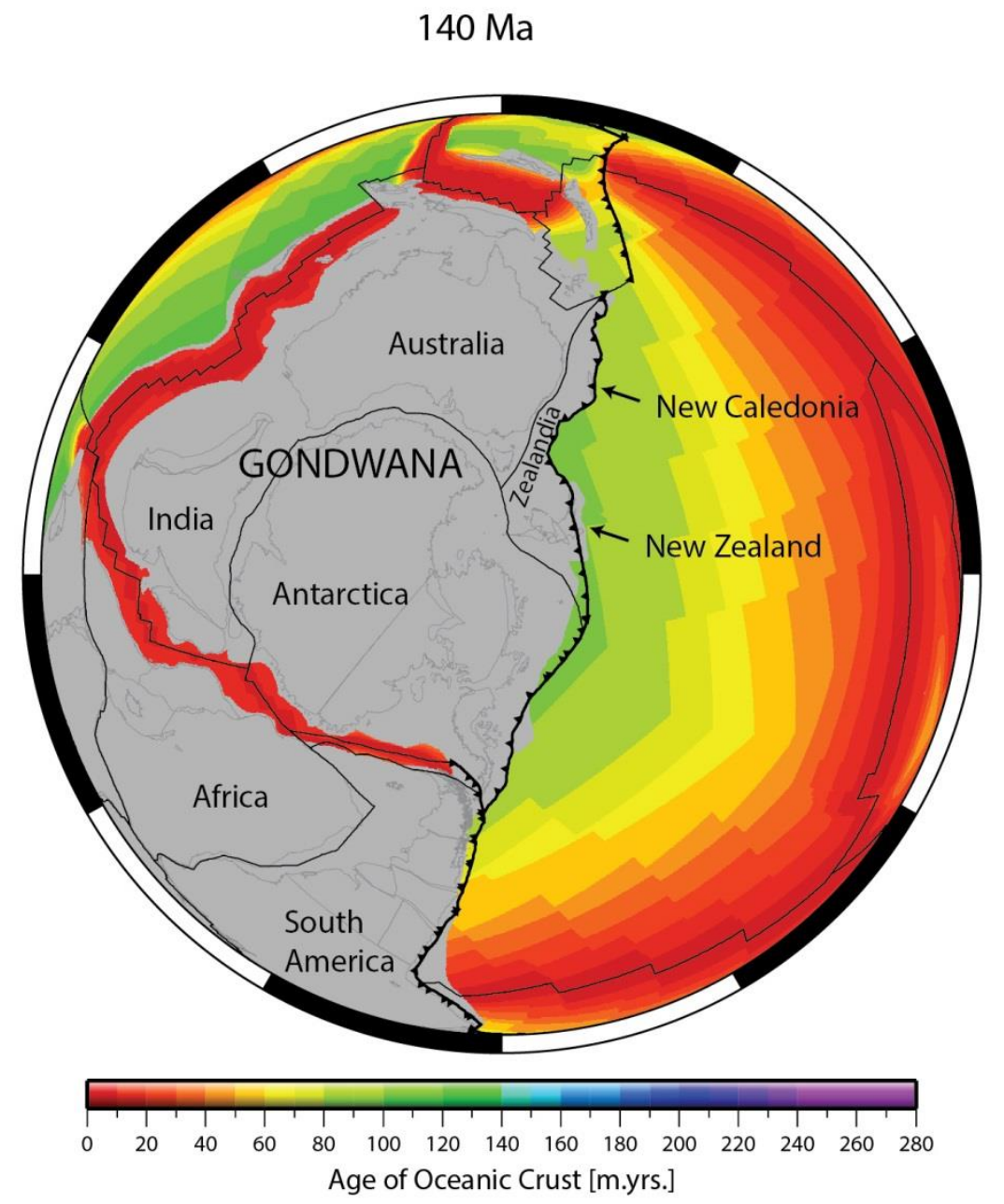

Figure 4 


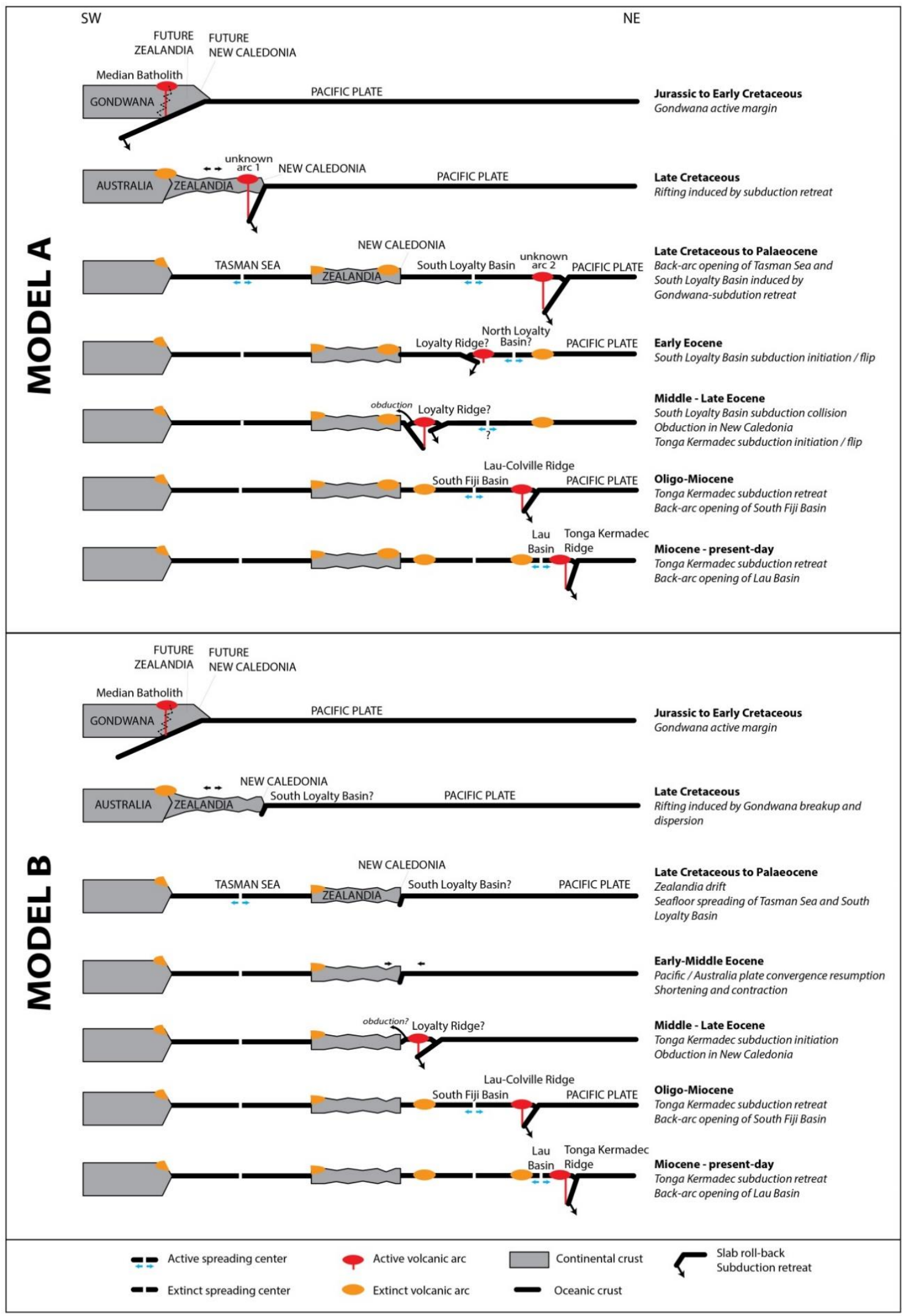

Figure 5 


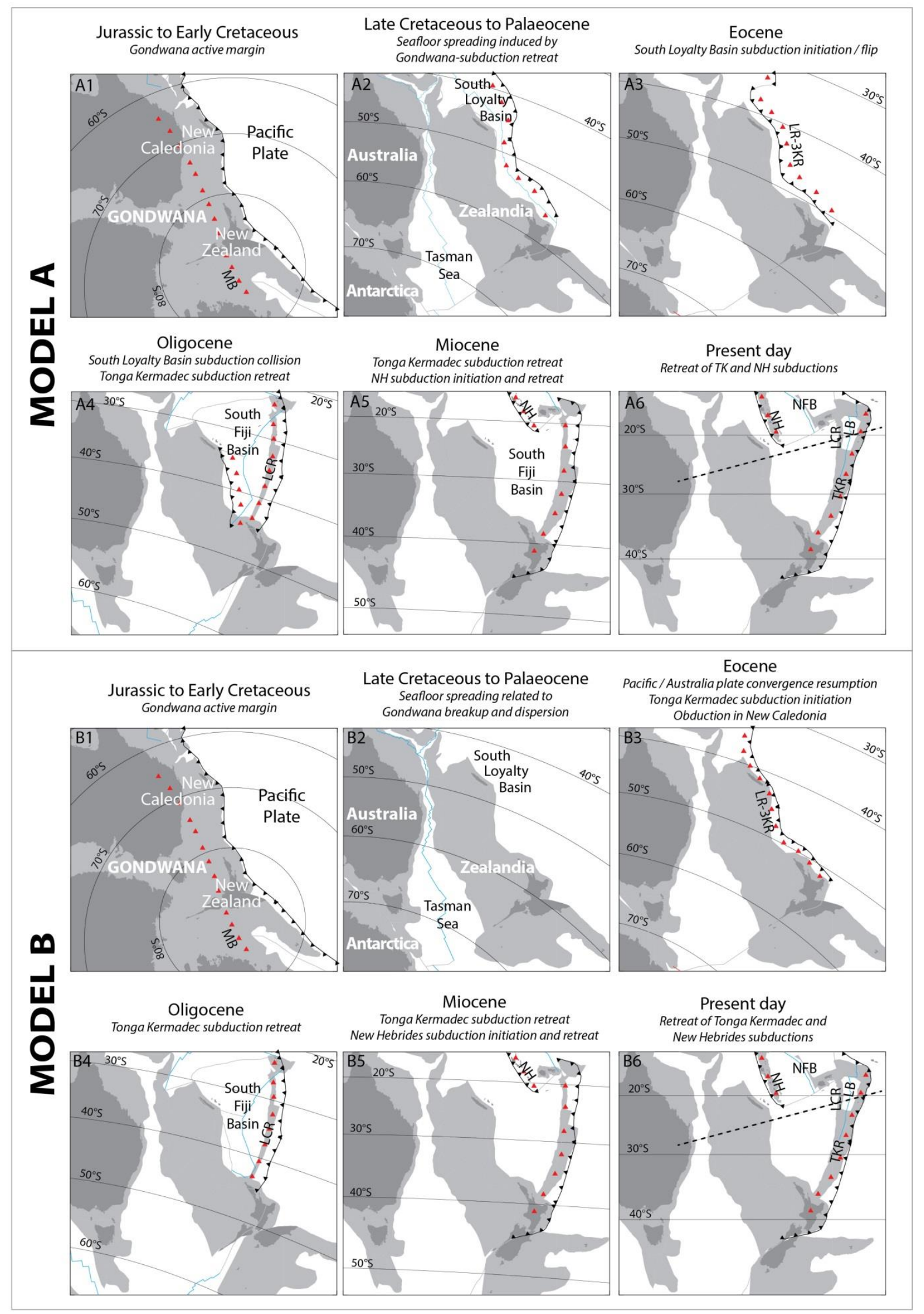

Figure 6 